\title{
On Plurality Category and Teaching in Turkish
}

\author{
Semra Aly1lmaz \\ Correspondence: Semra Aly1lmaz, K. K. Faculty of Education, Ataturk University, Erzurum, Turkey.
}

Received: July 9, 2017

Accepted: July 25, 2017

Online Published: August 8, 2017

doi:10.11114/jets.v5i9.2528

URL: https://doi.org/10.11114/jets.v5i9.2528

\begin{abstract}
When discussing about "plurality" of nouns in Turkish, it reminds /+lar/ affix after nouns (morpheme) and the subject is undervalued. Whereas, plurality and formation of plurality is not simple as it is thought as well as it is not made up of /+lar/ affix. It is because /+lar/ affix is only one of the linguistic elements in the morphological plurality used for making plural in Turkish.

Out of /+lar/ affix, /+An+/, /+Ar+/, /+(ş) $\mathrm{Ar}+/, /+\mathrm{GIl}+/, /+\mathrm{GUn}+/, /+{ }^{\circ} \mathrm{K}+/, /+1 \mathrm{~A}+/, /+{ }^{\circ} \mathrm{s}+/, /+{ }^{\circ} \mathrm{s}+/, /{ }^{\circ} \mathrm{T}+/, /+{ }^{\circ} \mathrm{z}+/$ affixes have given plurality, plus, double, group, generalization, exaggeration, respect etc. to the words they are added in the historical process of Turkish. However, a major part of affixes used in plurality by morphological ways in Turkish has lost their function of plurality etc. in the historical process and combined with the base, origin, and body of their words.

The plurality in Turkish is a name of category (as it is in all world languages) and made in three ways: Morphological plurality, semantic plurality, and syntactic plurality

In this article, information is given primarily in "generality" and "singularity" and secondarily in plurality in Turkish, ways of forming this category, and some problems in learning it.
\end{abstract}

Keywords: generality, singularity, plurality, and plurality category in Turkish and plurality category in teaching Turkish

\section{Introduction}

\subsection{On "Generality" and "Singularity" of Nouns in Turkish}

It is possible to examine Turkish linguistic elements under to headings which are "meaningful linguistic elements" and "functionary language elements" in Turkish in a holistic view. Meaningful linguistic elements are classified as nouns and noun-derivative words [nouns, adjectives (pronouns), adverbs, verbs, and verb-derivative words (simple verbs, derived verbs, and conflate verbs)]. Functionary linguistic elements are affixes, affixes+prepositions, prepositions, and conjunctions.

Among functional linguistic elements, nouns have categories of "generality", "singularity", and "plurality" categories (Gemalmaz, 1978: 263-267; Aly1lmaz, 1994: 37). When giving information related to the history and today of Turkish in some works, generally categories of generality and singularity have been neglected and plurality form has been made of introduction of some affixes and exemplification of some affixes which give plurality rather than a category. Whereas one (term sign) word/phrase has firstly a general base and its singularity and plurality forms/categories are made moving from this base.

There is no affix/form which shows/indicates general forms of noun words in Turkish (as it is in many world languages). In other words, general bases of the nouns have no mark ((non-marqué (ø)) (Gemalmaz, 2010: 257).

$1+^{\circ} \mathrm{n} /$ affix was used in singularity of Turkish words and this affix was either compounded with its word or gave its place to non-mark morpheme $(/+\varnothing /)$. Some words in historical source of Turkish (especially some words related to the names of organs and personal pronouns) indicate that.

Cengiz ALYILMAZ states in his article named "Zamir n'si Eski Bir İyelik Ekinin Kalıntısı Olabilir mi?" that nouns in Turkish has a $/+^{\circ} \mathrm{n} /$ morpheme showing singularity, it has transformed into non-mark $(/+\varnothing /)$ morpheme in time, and marks of this functional element are seen in some words:

$\mathrm{N}$ consonants at the end of first and second singular personal pronouns ( $b i+n>$ bin $>$ ben, $\operatorname{si}+n>\sin >\operatorname{sen}$ ) is not pronominal $\mathrm{n}$, in other words, archaic $\mathrm{n}$ of 3 rd personal affix, in our opinion but $/+^{\circ} \mathrm{n}+/^{\prime}$ which we consider an old singularity affix used in Turkish today without mark $/+\varnothing+/$. We see morpheme at the end of first and second personal pronouns (bi+n, si+n) $/+^{\circ} \mathrm{n}+/$ at the end of organ names such as alın, burun, 
karın, koyun, boyun. In double organ names, we generally see $/+z^{+/}$(diz, omuz, beniz, boynuz, göz...) and sometimes $/+\mathrm{K}+/$ (bilek, dirsek, kulak, topuk, ayak, bacak...) morphemes while $/+^{\circ} \mathrm{n}+/$ morpheme is used in this single organ names. The consonant $\mathrm{z}$ at the end of first and second plural personal pronouns (bi+z, si+z) is the $/+z+/$ which gives plurality (Alyılmaz, 1999: 411).

As ALYILMAZ states, $/+^{\circ} \mathrm{n} /$ morpheme at the end of nouns which shows singularity has given its place non-mark $(/+\varnothing /)$ morpheme in historical process of Turkish. More clearly, $\left(/+^{\circ} \mathrm{n} /\right)$ singularity category which is marked in the first periods of Turkish has become non-mark $(/+\varnothing /)$ in the future (and naturally today.

\section{Plurality in Turkish}

The word "Plurality" is defined in Turkish Dictionary published by Turkish Language Society as follows:

Plurality: 1. Being plural in number or meters, plural, abundance, majority, opposite of singularity. 2. Majority 3. The way in which the words express more than one existence or person, plural, togetherness.

4. Often, greatly, many times (Akalın etc., 2011: 560).

As a linguistic term, "Plurality" is defined in a similar way by the authorities of the matter and it is given place in studies conducted under the headings of "plurality", "plural", "plural suffix", "plurality suffix":

Plural: (Osm. cemi, Fr. pluriel, İng. plural, Alm. plural, mehrzahl, Derl. çokluk): The way of expressing multiple existences with certain suffixes or words: Evler, elmalar, ordular, evimiz, evlerimiz, biz, onlar etc.(Hatiboğlu, 1982: 36).

Plural suffix: Plural suffix which comes just after the noun bases and bodies do not establish a relationship between words. It only affects its word or phrase and it is separated from the other inflectional suffixes in this way. It shows plurality at the end of countable words and exaggeration at the end of non-countable words: evler, çocuklar, sular, soğuklar etc. It may fulfill the functions such as community, family, level, respect, and similarity by developing from them: babamlar, Ahmetler, onlar, yüzler, Atatürkler, Mustafa Kemaller etc.(Demir ve Y1lmaz, 2010: 206).

Plurality (Plural): There is number indication in all languages. Number is an information which we see in relationships of existence-existence and existence-action. The state of plurality of the existences is obtained by plurality inflection of them. Plurality inflection of nouns is not an association and inflection of compounding the phrase in other words. It is an noun inflection showing that the existence is multiple. Thus, plurality inflection elements function like derivational elements. The words which state the quantity of the existences in numbers are numerals. Nouns and pronouns of Turkish are in singularity-uncertain plurality relationship; there is no double or triple plurality or numbers in Turkish. It is morpheme stating existence or personal plurality and plurality inflection in this way; there is only innumerable plurality in Turkish as many other languages. Plurality inflection has been made with morpheme which has become suffix (Karaağaç, 2013: 253-254).

Plurality: Turkish which is a head-final language has tried and developed borrowing many plural suffix as well as generalization adjectives and numerals (For example: bir, iki, üç... birçok, bütün, her, çok, hiçbir ... etc.). It is seen that only / +1Ar+/continues to function (Gemalmaz, 2010: 257).

Plural suffix: (Alm. Pluralsuffix, pluralendung, pluralzeichen, Fr. désinence du pluriel, suffix du pluriel; İng. plural ending; Osm. Cemi lâhikası): Special suffixes used to express existences of the same type in nouns and pronouns: ağaç+ lar, çiçek+ler, oda+lar, bey+ler...(Korkmaz, 1992: 39).

Plurality category / Plural noun: Grammar category expressing the numbers in nouns in Turkish is called singularity and plurality. Noun bases and stems expressing a single object is defined with singular noun term. Noun bases and stems expressing more than one object is called plural noun (Üstünova, 2008: 384).

As can be understood from definitions and statements made, plurality is presented as "noun state which is opposite to the singularity and linguistic element expressing multiple state". Statements and definitions made for plurality is correct but enough. That is because plurality in Turkish is a name of category as all world languages. Suffixes/morphemes is not plurality itself but linguistic elements used in expression/formation of plurality. It is possible to examine plurality category of the nouns in three groups by considering historical development of Turkish (Gemalmaz, 1992: 112; Zeynalov, 1993: 106-116; Alyılmaz, 1994: 37-42; Alyılmaz, 1998: 27-30; Kerimoğlu, 2008: 140-155; Banguoğlu, 2004: 322-323; İlhan, 2009: 94-95; Alyılmaz, 2011: 107-109; Daşdemir, 2014: 62-65):

\section{Formation of plurality in morphologic way / Formation of plurality with suffixes}

2. Formation of plurality in semantic way / Formation of plurality with the words containing plurality in them 


\section{Formation of plurality in syntactic way / Formation of plurality in syntax}

\subsection{Formation of Plurality in Morphologic Way / Formation of Plurality with Suffixes}

Formation of plurality in morphologic way is made by addition plural suffixes to word bases. Thus, this formation of plurality is called "formation of plurality with suffixes".

Suffixes used in formation of plurality in the historical process of Turkish are ${ }^{1}: /+\mathrm{An}+/, /+\mathrm{Ar}+/, /+(\mathrm{s}) \mathrm{Ar}+/, /+\mathrm{GIl}+/$, $/+\mathrm{GUn}+/, /+{ }^{\circ} \mathrm{K}+/, /+1 \mathrm{~A}+/, /+1 \mathrm{Ar}+/, /+{ }^{\circ} \mathrm{s}+/, /+{ }^{\circ} \mathrm{s}+/, /+{ }^{\circ} \mathrm{T}+/, /+{ }^{\circ} \mathrm{z}+/ .{ }^{2}$

These suffixes stating that the term signs (of words/phrases) are multiple also express double, group, generalization, exaggeration, respect etc. However, a major part of suffixes out of $/+1 \mathrm{Ar}+/$ have merged and compounded with the word bases to which they are added in the historical process of Turkish.

It shall be benefit to present the suffixes used in morphological plurality and some words made in this way to the attention:

\subsection{1/ $+\mathrm{An}+/^{3}$}

$/+\mathrm{An}+/$ which is an old plural suffix has lost its function by today and merged with the bases and stems of word to which they are added. Their examples are not much: Turan, eren, bodun, örten (flames), kırkın (handmaidens, slaves), oğlan, kızan (children), köken, özen (essence, ore, ores, sap;), yegren (gazelle, gazelles)...

\subsection{2/+Ar+/, /+şAr+/}

/+Ar+/ ve /+şAr+/ which is one of the archaic plural suffixes of Turkey and used in clan names [Avar, Tatar, Av(ş)ar, Ogur $(<\mathrm{ok}+\mathrm{ur})$, Kazar $(>$ Hazar)] is used in numerals of distributive numeral adjective today: ikişer, üçer, dörder, beşer...

\subsection{3/+GIl+ $/^{4}$}

/+GIl+/ suffix provides plurality and generalization to the words to which they are added. Examples: İzgil, Çigil (<Çiøgil < Çik+gil), turunçgil, leylekgil(ler), üçgül, dörtgül, babamgil, dayımgil...

\subsection{4/+GUn+/}

/+GUn+/ suffix provides plurality and generalization to the words to which they are added. Examples: Taygun (valiant, sons such as foal), iniygün (small brothers), kelingün (brides), kadnagun (brothers-in-law), alkagun / alkugun (all, every), üçegün (three)...

\subsection{5/ $+^{\circ} \mathrm{K}+/$}

$/+^{\circ} \mathrm{K}+/$ suffix gives plurality, generalization, and double to which they are added. Examples: Sogdak, Çik, Kazak, Kumuk ( $<$ kumı $+\mathrm{k}<\mathrm{kom} 1+\mathrm{k}<\mathrm{kob}+\mathrm{k}$ ), çöbik (trashes), talak / talah (branches; tree, willow),kumak (sands, sand, beach), ayak, bacak, bilek, parmak, böbrek, dirsek, kulak, topuk, yanak, taşak, aşık (ankle bone)...

\subsection{6/ $+1 \mathrm{~A}+1$}

/+lA+/ is an archaic plural suffix. Their examples are not much: Atla (horses), tatla (tastes), ttla (dogs), ş̧la (works), aşla (meals), kışla (winters), bilgele (wises) (Poppe, 2008: 101-102; Ata, 2009: 89-99).

Use of $/+1 \mathrm{~A}+/$ morpheme in plurality are seen in some Turkish dialects (Karacai- Balkar Turkish and Turkmen Turkish [Zeynalov, 1993: 108]) and Anatolian dialects (Aydın dialect, Uşak dialect, Kütahya dialect, Edirne dialect, Kırklareli dialect, Çanakkale dialect...). Examples: ${ }^{5}$ Deligannılā (youngsters), genşlē (youths), gızlā (girls), memneketlē

\footnotetext{
${ }^{1}$ The suffixes in this chapter do not include plural suffices from Arabic and Persian in different periods.

${ }^{2}$ It is known that some suffixes gives plurality, abundance, majority, generalization etc. meanings added to the words (In Chuvash /+sAm+/; Turkish Language of Turkey and dialects/+II $+/, /+1 \mathrm{IK}+/, /+\mathrm{mAn}+/ /+\mathrm{TAş}+/ \ldots)$. Since suffix used in Chuvash $(/+\mathrm{sAm}+/)$ requires a separate research and suffixes used in Turkish Language of Turkey and dialects $(/+\mathrm{II}+/$, /+lIK+/, /+mAn+/, /+rAK+/, /+TAş $+/ . .$.$) are made adjective from nouns, they are not included in this group.$

$3 /+\mathrm{An}+/$ suffix is accepted as one of the common plurality of Altai. Scientists related with the subject relate / $+\mathrm{n}+/$ and/+nAr+/ plural suffixes with the word nay (person, public) in languages of Korean, Tunguz, and Mongolian. For further information, see Tekin, 2003: 190; Ersoy, 2012: 252.

${ }^{4}$ Feyzi ERSOY assesses this opinions related with the suffix in his article titled "+gil Eki Üzerine" and states that this suffix is a word which is same or related with kil which means "home, family". (Ersoy, 2009: 21-29). There are different opinions related to the structure of the suffix. For detailed information see Gülsevin, 2004:1267-1284; İlhan, 2009: 113-122.

${ }^{5}$ It is understood that $/+1 \mathrm{~A}+/$ plural suffix in these examples used in Anatolian dialects is formed by haplology of $-\mathrm{r}$ consonant at the end of $/+1 \mathrm{~A}+/$ suffix $(/+1 \mathrm{Ar}+/>/+1 \mathrm{~A} \varnothing+/>/+1 \mathrm{~A}+/)$.
} 
(countries), bābālāmız (fathers), (Uşak Ağzı; Gülsevin, 2002: 168; Kırklareli Ağzı; Günşen, 2008: 41).

2.1.7 / +1Ar+/

$/+1 \mathrm{Ar}+/$ is a plural suffix having been used since the oldest written sources of Turkish. There are different opinions related to $/+1 \mathrm{Ar}+/$ plural suffix. A part of researchers state that this suffix is made of personal pronoun of ol and $/+\mathrm{r} /$ suffix, some believe that it is made of composition of $/+1+/$ and $/+\mathrm{Ar}+/$, and a part believes that it is made of composition of /+1A+/ and / $+\mathrm{r}+/$ (Deny, 1937: 291-295; Emre, 1943: 199-207; Kösearif, 1948: 13-15; Sinor, 1952: 203-230; Caferoğlu, 1984: 140; Alyılmaz, 1994: 39; İsina, 1997: 113-118. Tekin, 2003: 183-195; Üstünova, 2008: 384; Buran, 2008: 153-159; İlhan, 2009: 57-99; Ersoy, 2012: 250-259).

/+1Ar+/ plural suffix is used in Turkish dialects as /+TAr+/, /+TOr+/, /+1Or+/, /+nAr+/, /+nOr+/, /+zAr+/ (Zeynalov, 1993: 107.

$+1 \mathrm{Ar}+$ / suffix also expresses generality, togetherness, respect, exaggeration: elmalar, armutlar, kurtlar, kuşlar, okullar, kitaplar, dergiler, beyler, paşalar, günler, aylar, yıllar, kediler, köpekler, hanlar hamamlar, saraylar, Aliler, Veliler...

$2.1 .8 /+^{\circ} \mathrm{s}+/, /+^{\circ} \mathrm{s}+/$

$1+^{\circ} \mathrm{s}+/, 1+^{\circ} \mathrm{s}+/$ suffixes provides plurality and generality to the words to which they are added. Examples: Kengeres, işbaraş, Türgiş, Tarduş, oguş (ok+uş: clans), ödüş (times), arkış (caravan), bagış (vines), bögüş / bügüş (wises, wizards), tirkiş (caravan), yış (forest), kayas / kayaş (stones, rocks), agış (fortune, fortunes), diş, kaş, geniş, güneş... Examples:

2.1.9 $/+^{\circ} \mathrm{T}+/^{6}$

$1+{ }^{\circ} \mathrm{T}+/$ frequently seen in Ancient Turkish Language Period generally state plurality and generalization: tarkat (tarkans), oglit (children), apat / apıt (sisters mothers), bayagut (riches, assets), alpagut (valiant, hero, brave), y1lpagut (yvaliant, hero, brave), urungut (director,admin,chairman,chief,head), sengüt (generals), beget (sirs), tigit (tigins, princes), erat / eret (males, soldiers, valiants), yiğit (valiants, braves), sıgıt (sadness, distress), yaşıt, boyut, eşit, karşıt, bört (< börit: worms, bugs), kanat, kulut (slaves, serfs), süt, Sakait (> ..> İskit), Türküt, Tangut, Bayat, Bugut, Ongut / Öngüt, Soğut (Sogut $<$ Suk + ut), Mançud $(<$ Mançu+t), Teleüt...

2.1.10 / ${ }^{\circ} \mathrm{Z}+/$

$1+^{\circ} \mathrm{z}+/$ which is an archaic plural suffix and seen in organs and clans in first and second personal pronouns gives plurality, generalization, and double to which they are added. Examples: Ediz, Oguz $(<\mathrm{ok}+\mathrm{uz}), \operatorname{Kirg} 1 \mathrm{z}(<\mathrm{kırk}+\mathrm{rz})$, yabız (bad, badness), agız, diz, göz, kögüz (> chest), omuz, beniz, boynuz, biz, siz, ikiz, üçüz, dördüz, beşiz...

\subsection{Formation of Plurality in Semantic Way / Formation of Plurality with the Words Containing Plurality in Them}

Some (Turkish or quote) words in stem or base form in Turkish have abundance, vastness, quantity, and group. Use of such words during transmission/conveyance of information/message between transmitter and receiver by semantic way is called formation of plurality. Example: Tümen (ten thousand), telim (many), üküş (many), köp (many), çok, ulu, yüce, büyük, sü (army), ordu, goşun (army), bölük (company, troop), takım, manga, tabur, yış (forest), orman, tokoy (forest), taluy (ocean; sea), deniz, sürü, toplum, düzine, aşırı, bol...

\subsection{Formation of Plurality in Syntactic Way / Formation of Plurality in Syntax}

The most frequently used method in historical process of Turkish is undoubtedly is syntactic method. In this method, possessive construction and adjective clause which have plurality meaning, repetitive groups, handiadyoin etc: Ada tuda (danger, calamity), adruk adruk (Separately, another, different kinds), öngi öngi (Separately, another, different kinds), yabız yablak (bad, very bad), eb bark (home), el uluş (foreigner, public, everybody), ed tavar (Wealth goods; Wealth state), sü çerig (Army soldier), yagı yavlak (Enemy, evil; Enmity), ters yavlak ayıg (contrary, bad, dirty), tapıg udug agır ayag (Respect, wonderment, worship), yıdıg sarsıg (Bad smell, odor, filthy), neñ neñ (many, existence), kucak kucak, sepet sepet, avuç avuç, katar katar, deste deste, yığın yığın, akın akın, oğul uşak, pek çok, açık açık, apaçık, upuzun, depderin, sapsarı, dupduru, kıpkırmızı, çırılçıplak, sırılsıklam, bambaşka, yemyeşil, koskocaman; büyük göç, pek çok insan, iki bin sekiz yüz yetmiş beş kişi, otuz beş bin koyun, yirmi bin inek...

\section{Some Recommendations on Plurality Category and Teaching in Turkish}

When discussing formation of plurality (as mentioned above), "formation of plurality in morphological way / formation of plurality with suffixes" comes to mind. Plurality category is presented under headings of "plural suffix", "plurality affix" etc. in studies conducted and published in relation with the subject (in linguistic books, term dictionaries etc.).

${ }^{6}$ For detailed information related to $/+^{\circ} \mathrm{T}+/$ accepted to be one of the plural suffixes of Altai, see, Korkmaz, 1986: 47-48; Aly1lmaz,1994: 39; Tekin, 2003: 183-195; Demir, 2005: 437-441; Poppe, 2008: 93-110; İlhan, 2009: 104-106; Ersoy, 2012: 250-259. 
Whereas, plurality is not the name of a suffix or suffixes but the category. For this reason:

- Plurality must be thought in the related departments and classes at every stage of education starting from primary school.

- Since plurality is not thought as category but only formation of plurality in morphologic way, the formation methods frequently used in plurality in Turkish (formation of plurality in semantic and syntactic method) are avoided and not known. At today's point, a major part of linguistic elements (suffixes) in historical process of Turkish has lost its functions, merged with the bases and stems of the words, and naturally only /+1Ar+/ plurality suffix stands out.

- When formation of plurality in morphological way in Turkish, /+lAr+/ morphemes and functions are stated. The works and course books related with the subject must include suffixes stating abundance, vastness, community, generalization, double etc. (/+An $+/, /+\mathrm{Ar}+/, /+\left(\right.$ ş) $\mathrm{Ar}+/, /+\mathrm{GIl}+/, /+\mathrm{GUn}+/, /+{ }^{\circ} \mathrm{K}+/, /+1 \mathrm{~A}+/, /+{ }^{\circ} \mathrm{s}+/, 1+{ }^{\circ}$ ş $\left.+/, /+{ }^{\circ} \mathrm{t}+/, /+^{\circ} \mathrm{z}+/\right)$ and the functions of these suffices; meronymy must be thought to target population. Human mind firstly perceives "whole" and then realize parts and details. The order of perception -if there is no specific condition- the starting point of meronymy shall be "whole". Establishing correct relationship between the parts becomes possible by merging these parts and deliberately recognize the whole. Meronymy is closely related with the teaching of the language which holds various wholes consisting of parts (Karahan, 2011: 303).

It is imperative to show meronymy for Turkish which is the most characteristic example of agglutinative languages in terms of structure and to teach functions between meaningful and functionary linguistic elements in terms of linguistic and language teaching.

\section{References}

Akalin, S. H. etc. (2011). Turkish dictionary. Ankara.

Alyilmaz, C. (1994). Syntax of Orhun inscriptions. Erzurum.

Alyilmaz, C. (1999). Can the pronoun "n" be a remnant of an old possessive suffix? Turk Gramerinin Sorunları II, Ankara, 403-415.

Alyilmaz, S. (1998). Syntax of D'Uygur version the story of 'Prens Kalyanamkara Paramkara. (Ataturk University Social Sciences Institute, Master's Thesis), Erzurum.

Alyilmaz, S. (2011). Risale-i muze-duzluk (Review - Text - Directory). Ankara.

Ata, A. (2009). + 1A multiplicity suffix in Turkic languages. International Journal of Central Asian Studies, 13, 89-99.

Banguoglu, T. (2004). The grammar of Turkish. Ankara.

Buran, A. (2008). Suffix of Turkic words and the root of suffixes. Articles, 153-159, (Prepared E. Alkaya, S. K. Yalcin ve M. Sengul).

Caferoglu, A. (1984). Turkic language history. İstanbul.

Dasdemir, M. (2014). The method with arrow syntax of structural - functional of Turkish. Erzurum.

Demir, N. (2005). The about multiplicity suffix +(I)t / +(I)t. Turk Dili Dil ve Edebiyat Dergisi, 647, 437-441.

Demir, N., \& Yilmaz, E. (2010). The handbook of Turkish language. Ankara.

Deny, J. (1937). Origin of the preposition 'ler' in Turkish language. III. Turk Dil Kurultayi Bildirileri, İstanbul, 291-295.

Emre, A. C. (1943). The name basics in Turkish language. İstanbul.

Ersoy, F. (2007). On the suffix + gil. Dil Arastirmalari Dergisi, 1/1, 21-29.

Ersoy, F. (2012). Turkish-Mongolian language relation and Chuvash. Ankara.

Gemalmaz, E. (1978). Erzurum province dialects (review text word and directory) I. Ankara.

Gemalmaz, E. (1992). The informative values of the standard Turkish language formants and the possible effects of these values on the development of this language if necessary. Erzurum.

Gemalmaz, E. (2010). Deep structure of Turkic. Ankara, (Prepared C. Alyilmaz ve O. Mert).

Gulsevin, G. (2002). Language features of Uşak provinces dialects - Texts - Dictionary. Ankara.

Gulsevin, G. (2004). "Unusual suffixes" in Turkish language and on the problem of classification - identification of suffixes. V. Uluslararasi Turk Dili Kurultayi Bildirileri I, 20-26 Eylul 2004, Ankara, 1267-1284.

Gunsen, A. (2008). Main characteristics which define the morphology of East Thrace dialect. Turkish Studies International Periodical For the Languages, Literature and History of Turkish or Turkic, 3/3, 402-470. 
Hatiboglu, V. (1982). Grammar terms glossary. Ankara.

Isina, A. (1997). Multiplicity in Siberia dialects. Sibirya Arastirmalari, İstanbul, (Prepared E. Gursoy-Naskali), $113-118$.

İlhan, N. (2009). Multiplicity in Turkish language. Istanbul.

Karaagac, G. (2013). Linguistic terms glossary. Ankara.

Karahan, L. (2011). The importance of whole-parts relation in teaching grammar. Turk Dili Uzerine Incelemeler, 300-305.

Kerimoglu, C. (2008). Plurality and optative categories in Turkey Turkish grammarianship. Journal of Modern Turkish Studies, 5/3, 140-155.

Korkmaz, Z. (1986). Elements common between Turkish and Mongolian and the place of Mongolian in Turkish language research. TDAY Belleten 1986, 43-52.

Korkmaz, Z. (1992). Grammar terms glossary. Ankara.

Kosearif, F. (1948). What is the origin of plural suffix? TDAY-B III / 10-11, İstanbul, 13-15.

Poppe, N. (2008). Multiplicity suffixes in Altai languages. Dil Arastırmalari Dergisi, 2, 93-110, cev. C. Kerimoglu.

Sinor, D. (1952). On some ural-altaic plural suffixes. Asia Major, 2, 203-230.

Tekin, T. (2003). A grammar of Orkhon Turkic. İstanbul.

Tekin, T. (2003). Remarks on a study in Altaic comparative morphology. Makaleler I Altayistik, Ankara, 183-195, (Prapared E. Yilmaz - N. Demir).

Ustunova, K. (2008). Name operation of Turkey Turkish (morphology). İstanbul.

Zeynalov, F. (1993). Comparative grammar of Turkish dialects. İstanbul, (Tra. Y. Gedikli).

\section{Copyrights}

Copyright for this article is retained by the author(s), with first publication rights granted to the journal.

This is an open-access article distributed under the terms and conditions of the Creative Commons Attribution license which permits unrestricted use, distribution, and reproduction in any medium, provided the original work is properly cited. 